dy w nim zamieszczone wchodzą do kanonu wykształcenia. Tym zaś, którzy to dzieło tworzą należy się szacunek i wdzięczność.

Kraków

KS. KAZIMIERZ PANUŚ

ks. Tadeusz Matras

\title{
TEMATY ROZPRAW DOKTORSKICH Z ZAKRESU LITURGIKI NAPISANYCH W KRAKOWIE
}

\section{NA PAPIESKIM WYDZIALE TEOLOGICZNYM}

1. ks. DZIWISZ STANISŁAW (archidiecezja krakowska), 1981 - Kult św. Stanistawa w Krakowie do Soboru Trydenckiego, promotor: ks. doc. dr hab. Wacław Schenk

2. ks. KOPEREK STEFAN CR (Zgromadzenie Księży Zmartwychwstańców), 1977 - Teologia roku liturgicznego wedtug Prospera Guerangera OSB, promotor: ks. doc. dr hab. Wacław Świerzawski

3. ks. PIOTROWSKI EUGENIUSZ (diecezja opolska), 1988 - Działalność liturgiczno-duszpasterska ks. Gerarda Szmyda (1885-1938), promotor: ks. doc. dr hab. Wacław Schenk

4. ks. SinKA TARSYCJUSZ CM (Zgromadzenie Księży Misjonarzy Lazarystów), 1980 - Kult św. Józefa w polskich pieśniach nabożnych ku Jego czci, promotor: ks. doc. dr hab. Wacław Schenk

5. ks. ZIMOŃ DAMIAN (diecezja katowicka), 1977 - Uczestnictwo wiernych we Mszy świętej na ziemiach polskich $w$ XIX wieku $w$ świetle modlitewników i podręczników liturgicznych, promotor: ks. doc. dr hab. Wacław Schenk

\section{NA WYDZIALE TEOLOGICZNYM PAPIESKIEJ AKADEMII TEOLOGICZNEJ}

1. ks. BurzaWA StanisŁaW (diecezja tarnowska), 1993 - Rozwój teologii Adwentu, promotor: ks. bp prof. dr hab. Wacław Świerzawski

2. ks. CELARY JANUSZ (archidiecezja katowicka), 1998 - Obrzędowość świecka w Polsce (1944-1989) jako wezwanie dla współczesnego życia duszpastersko-liturgicznego, promotor: ks. prof. dr hab. Stefan Koperek $\mathrm{CR}$ 
3. ks. DYL ANDRZEJ GERARD (diecezja tarnowska), 1982 - Michat Giedroyć (1425-1455) z zakonu Kanoników Regularnych od Pokuty Błogosławionych Męczenników. Życie i kult, promotor: ks. prof. dr hab. Wacław Świerzawski

4. ks. GREGER PIOTR (diecezja bielsko-żywiecka), 2000 - Percepcja obrzedów pokuty $w$ Polsce po Soborze Watykańskim II. Studium liturgicznoduszpasterskie, promotor: ks. prof. dr hab. Stefan Koperek CR

5. ks. JACKOWSKI-FEDOROWICZ SZYMON (archidiecezja krakowska), 1996 Biblijne obrazy Kościoła u niektórych autorów chrześcijańskich wedtug Jean Danielou SJ $i$ ich zastosowanie $w$ chrześcijańskim wtajemniczeniu dorostych, promotor: ks. bp prof. dr hab. Wacław Świerzawski

6. ks. KONECNY ANTON (diecezja koszycka, Słowacja), 1997 - Historia i teologia słowackich pieśni religijnych a ich adaptacja do liturgii po Soborze Watykańskim II, promotor: ks. doc. dr hab. Stefan Koperek CR

7. ks. MOJŻESZKO ANDRZEJ (diecezja bielsko-żywiecka), 2000 - Idea Miłosierdzia Bożego w mszale rzymskim Pawła VI, promotor: ks. prof. dr hab. Stefan Koperek CR

8. ks. NANOWSKI JANUSZ (archidiecezja krakowska), 1983 - Liturgia Wielkiego Postu po Soborze Watykańskim II. Aspekt katechetyczny i implikacje duszpasterskie, promotor: ks. prof. dr hab. Wacław Świerzawski

8. ks. NEPSINSKY VOJTECH (diecezja koszycka, Słowacja), 1997 - Liturgia na Stowacji w okresie Soboru Trydenckiego, promotor: ks. doc. dr hab. Stefan Koperek CR

9. ks. RAGAN GABRIEL (diecezja koszycka, Słowacja), 2000 - Ruch liturgiczny na Stowacji, promotor: ks. prof. dr hab. Stefan Koperek CR

10. ks. SADKO ZDZISŁAW (diecezja tarnowska), 1996 - Percepcja soborowej odnowy liturgicznej $w$ diecezji tarnowskiej za pasterzowania księdza arcybiskupa Jerzego Ablewicza (1962 -1990), promotor: ks. doc. dr hab. Stefan Koperek CR

11. s. SIELEPIN ADELAJDA CHR (Zgromadzenie Sióstr św. Jadwigi królowej Służebnic Chrystusa Obecnego), 1995 - Przyszła chwała zbawionych $w$ sakramentach chrześcijańskiego wtajemniczenia, promotor: ks. bp prof. dr hab. Wacław Świerzawski

12. ks. TYRAŁA ROBERT (z archidiecezji krakowskiej), 2000 - Soborowa odnowa muzyki kościelnej i jej percepcja w Polsce, promotor: ks. prof. dr hab. Stefan Koperek CR 